\title{
КОРПОРАТИВНІ ОБЛІГАЦІЇ ЯК ДЖЕРЕЛО РОЗВИТКУ ФІНАНСОВОГО ПОТЕНЦІАЛУ СУБ'СКТІВ ГОСПОДАРЮВАННЯ
}

DOI: $10.32620 /$ cher.2021.2.07

Постановка проблеми. Успішність функціонування суб'єктів господарювання залежить від можливостей вчасного залучення необхідного обсягу фінансових ресурсів для здійснення діяльності. Одним із актуальних питань щодо залучення капіталу шляхом емісії корпоративних облігацій $\epsilon$ визначення факторів та тенденцій, що впливають на цей процес в контексті розвитку фінансового потенціалу суб'єктів господарювання. Метою статті є аналіз сучасного стану емісійної активності суб'єктів господарювання та визначення впливу емісії корпоративних облігацій на формування капіталу суб'єктів господарювання. Предмет дослідження - формування капіталу шляхом випуску облігацій в контексті розвитку фінансового потенціалу суб'єктів господарювання. Методи, використані в дослідженні: узагальнення, порівняння, трендовий аналіз, моделі трендів. Виклад основного матеріалу. У статті висвітлено особливості корпоративних облігацій як додаткового джерела розвитку фінансового потенціалу суб'єктів господарювання. Проаналізовано стан та динаміку емісійної активності суб'єктів господарювання щодо випуску облігацій та активності на вторинному ринку корпоративних облігацій. Сформовано модель нелінійної регресії, що віддзеркалює динаміку емісійної активності суб'єктів господарювання. Побудовано поліноміальну модель залежності капіталу від емісій облігацій суб’єктів господарювання. Практичне значення одержаних результатів полягає в можливості застосування побудованих моделей в процесі формування стратегії фінансового регулювання розвитку суб'єктів господарювання. Висновки дослідження. Потенційним джерелом фінансування розвитку суб'єктів господарювання є корпоративні облігації. Трендовий аналіз емісійної активності підприємств щодо випуску корпоративних облігацій свідчить про недостатню розвиненість цього сегменту фондового ринку. В процесі дослідження фінансового потенціалу розвитку суб'єктів господарювання слід враховувати залежність сформованого капіталу та емісійної активності, активність на вторинному ринку корпоративних облігацій. Побудовані моделі нелінійної регресії динаміки емісій облігацій та поліноміальна модель залежності капіталу від емісій облігацій суб'єктів господарювання дасть змогу підвищити об’єктивність прогнозування.

Ключові слова:

фінансовий потенціал, корпоративні облігації, емісійна активність, ринок цінних паперів, капітал.

\section{CORPORATE BONDS AS A SOURCE OF DEVELOPMENT OF FINANCIAL POTENTIAL OF BUSINESS ENTITIES}

Formulation of the problem. The success of business entities depends on the ability to attract the necessary amount of financial resources to carry out activities. One of the most important issues in raising capital through the issuance of corporate bonds is to identify the factors and trends that affect this process in the context of developing the financial potential of economic entities. The aim of the research is to analyze the current state of the issue activity of business entities and determine the impact of the issue of corporate bonds on the capital formation of business entities. The subject of the research is the formation of capital through the issuance of bonds in the context of the development of the financial potential of economic entities. The methods of the research: generalization, comparison, trend analysis, trend models. The statement of basic materials. The article highlights the features of corporate bonds as an additional source of development of the financial potential of economic entities. The state and dynamics of issue activity of business entities on bond issue and activity on the secondary market of corporate bonds are analyzed. A nonlinear

${ }^{1}$ Середа Олена Олександрівна, канд. екон. наук, старший викладач кафедри фінансів та банківської справи, Східноукраїнський національний університет імені Володимира Даля, Сєвєродонецьк, Україна.

Sereda Olena, Ph.D. of Economics, Senior lecturer of Finance and Banking Department, Volodymyr Dahl East Ukrainian National University, Severodonetsk, Ukraine.

ORCID ID: 0000-0003-0547-2077

e-mail: sered1010@gmail.com 
regression model has been formed, which reflects the dynamics of emission activity of economic entities. A polynomial model of capital dependence on bond issues of economic entities has been built. The practical significance of the research lies in the possibility of applying the built models in the process of forming a strategy of financial regulation of the development of economic entities. Conclusions and perspectives of further research. Corporate bonds are a potential source of financing for the development of economic entities. Trend analysis of the issue activity of enterprises on the issue of corporate bonds indicates the underdevelopment of this segment of the stock market. In the process of studying the financial potential of the development of economic entities should take into account the dependence of the formed capital and emission activity, activity in the secondary market of bonds of economic entities. The constructed models of nonlinear regression of the dynamics of bond issues and the polynomial model of the dependence of capital on bond issues of economic entities will increase the objectivity of forecasting.

Key words:

financial potential, corporate bonds, issue activity, securities market, capital.

\section{КОРПОРАТИВНЫЕ ОБЛИГАЦИИ КАК ИСТОЧНИК РАЗВИТИЯ ФИНАНСОВОГО ПОТЕНЦИАЛА СУБЪЕКТОВ ХОЗЯЙСТВОВАНИЯ}

Постановка проблемы. Успешность функционирования субъектов хозяйствования зависит от возможностей своевременного привлечения необходимого объема финансовых ресурсов для осуществления деятельности. Одним из актуальных вопросов привлечения капитала путем эмиссии корпоративных облигаций является определение факторов и тенденций, влияющих на этот процесс в контексте развития финансового потенциала субъектов хозяйствования. Целью статьи является анализ современного состояния эмиссионной активности субъектов хозяйствования и определения влияния эмиссии корпоративных облигаций на формирование капитала субъектов хозяйствования. Предмет исследования - формирование капитала путем выпуска облигаций в контексте развития финансового потенциала субъектов хозяйствования. Методы, использованные в исследовании: обобщение, сравнение, трендовый анализ, модели трендов. Изложение основного материала. В статье освещены особенности корпоративных облигаций как дополнительного источника развития финансового потенциала субъектов хозяйствования. Проанализировано состояние и динамика эмиссионной активности субъектов хозяйствования по выпуску облигаций и активности на вторичном рынке корпоративных облигаций. Сформирована модель нелинейной регрессии, которая отражает динамику эмиссионной активности субъектов хозяйствования. Построено полиномиальную модель зависимости капитала от эмиссий облигаций субъектов хозяйствования. Практическое значение полученных результатов заключается в возможности применения построенных моделей в процессе формирования стратегии финансового регулирования развития субъектов хозяйствования. Bblводы исследования. Потенциальным источником финансирования развития субъектов хозяйствования являются корпоративные облигации. Трендовый анализ эмиссионной активности предприятий по выпуску корпоративных облигаций свидетельствует о недостаточной развитости этого сегмента фондового рынка. В процессе исследования финансового потенциала развития субъектов хозяйствования следует учитывать зависимость сформированного капитала и эмиссионной активности, активности на вторичном рынке корпоративных облигаций. Построенные модели нелинейной регрессии динамики эмиссий облигаций и полиномиальная модель зависимости капитала от эмиссий облигаций субъектов хозяйствования позволит повысить объективность прогнозирования.

\section{Ключевые слова:}

финансовый потенциал, корпоративные облигации, эмиссионная активность, рынок ценных бумаг, капитал.

Постановка проблеми. В сучасних умовах національної економіки успішність функціонування суб'єктів господарювання залежить від можливостей вчасного залучення необхідного обсягу фінансових ресурсів для здійснення поточної та інвестиційної діяльності. Ринок корпоративних облігацій забезпечує емітентів переважно довгостроковим капіталом шляхом створення альтернативних джерел фінансування. Використання механізмів залучення капіталу шляхом емісії облігацій суб'єктами господарювання сприяє пом'якшенню негативних наслідків впливу фінансової кризи, якщо інші канали фінансування будуть недоступні. У перспективі, конкуруючи з банківським кредитуванням, корпоративні облігації поступово дозволять зменшити вартість запозичених коштів, що буде сприятиме швидшому розвитку реального сектора економіки. Саме корпоративні облігації можуть виступати джерелом капіта- 
лу для його динамічного розвитку, створення конкурентних переваг, розширення його діяльності, створенню і реалізації інноваційної продукції. 3 огляду на вищезазначене, актуалізується необхідність узагальнення тенденцій, виокремлення проблем, пов'язаних 3 залученням капіталу шляхом емісії корпоративних облігацій та побудові прогнозних моделей, що буде сприятиме прийняттю рішень щодо вибору зовнішніх джерел фінансування.

Аналіз останніх досліджень i публікацій. Проблеми процесів залучення капіталу традиційно знаходяться у центрі уваги дослідників та отримали висвітлення у науковій економічній літературі.

Питання визначення параметрів облігацій та факторів впливу на дохідність корпоративних облігацій на ринку цінних паперів $є$ предметом дослідження зарубіжних вчених. М. Флемінг і Н. Крішнан [1] вивчали державні облігації в США, а Б. Біас і Р. Грін [2] досліджували особливості корпоративних та муніципальних облігації. Зміни ціни корпоративних облігацій та премію, яку пропонують інвесторам за рентабельність цінних паперів розглянув Г. Стефані [3] на основі огляду від теоретичних моделей до емпіричних детермінант цін на корпоративні облігації. В свою чергу Го Хайфенг, Контонікас Александрос і Майо Пауло [4] зробили припущення, що шоки грошово-кредитної політики впливають на дохідність корпоративних облігацій. Вони отримали значну негативну реакцію повернення облігацій на шоки, що особливо проявилось серед низькокласних облігацій. Це було пов'язано 3 більш високим очікуваним прибутком за облігаціями (премією за ризик) у порівнянні 3 очікуванням майбутніх процентних ставок. Е. Нувеллон, Х. Пірот Шпедер [5] запропонували методичний підхід до синтетичної структури похідних інструментів власного капіталу, що імітує поведінку грошових потоків у портфелі корпоративних облігацій.

Механізми залучення капіталу шляхом емісії облігацій та функціонування ринку боргових цінних паперів розглянуто в дослідженнях вітчизняних вчених: І.В. Білоус [6], Т.Д. Косової, Л.А. Костирко, М. О. Кужелєва [7], А. Пересади, В.В. Зимовця, В.В. Руденко [8], М.В. Стецько [9], І. Є. Якушевої [10] та інших.

Стецько М.В. [9] в досліджені визначив детермінанти премії за ризик вкладень у кор- поративні облігації в Україні, основним 3 яких є: фактор ліквідності ринку загалом та конкретних цінних паперів, ризик зміни відсоткових ставок, ризик дефолту емітенті

Науковці Кужелєв М. О., Стабіас С. М. [8] підкреслюють, що «...функціонування ринку корпоративних цінних паперів $\epsilon$ важливою складовою фінансового сектора економіки та регулятором процесів ринкової системи країни». Вони запропонували модель функціонування ринку корпоративних цінних паперів в основі якої покладено аналіз його структурних та часових властивостей. Важливим результатом дослідження Кужелєв М. О., Стабіас С. М. є визначення залежності «динаміки цін на корпоративні цінні папери від внутрішніх пріоритетів; від зовнішніх пріоритетів (курсу національної валюти до дол. США); від випуску корпоративних цінних паперів та динаміки часу». Практичне застосування дескриптивної моделі дозволило авторам визначити чинники, що найбільш суттєво впливають на розвиток ринку корпоративних цінних паперів: інфляція, рівень розвитку економіки, процентні ставки за альтернативними фінансовими інструментами.

Якушева I. Є. [10] приділила увагу визначенню місць, розкрито місця та ролі різних груп учасників вітчизняного ринку облігацій, а також їх «значенню в ефективному функціонуванні боргового сегмента фондового ринку».

В дослідженні Білоус І.В. [6] окреслено «проблеми, що стримують емісійну активність у реальному секторі економіки країни» та обгрунтовано причини слабкої активності фізичних осіб на ринку облігацій. Наукова робота Руденко В.В. [8] присвячено порівняльному аналізу сучасного стану ринку корпоративних облігацій в Україні у порівнянні 3 розвиненими країнами світу. Дослідник робить висновок про «відставання цього сегменту фінансового ринку за обсягами залучених фінансових ресурсів» та потенційність ринку корпоративних облігацій, як потужного джерела залучення капіталу суб'єктами господарювання, що, в свою чергу, вимагає сприяння його з боку держави.

Незважаючи на значний обсяг досліджень щодо інструментів та механізмів залучення фінансових ресурсів підприємств шляхом емісії облігацій, подальшого дослідження потребують визначення факторів та тенденцій, що впливають на цей процес, в 
контексті розвитку фінансового потенціалу суб'єктів господарювання.

Метою статті $\epsilon$ аналіз сучасного стану емісійної активності суб'єктів господарювання та визначення впливу емісії корпоративних облігацій на формування капіталу суб'єктів господарювання.

Виклад основного матеріалу дослідження. Довгостроковий позиковий капітал корпорацій формується за рахунок емісії корпоративних облігацій $[9,11]$.

Випуск корпоративних облігацій здійснюється у разі виникнення таких потреб [12]:

1) залучення додаткового капіталу без «розмивання» власності;

2) залучення додаткового капіталу з метою покриття дефіциту оборотних коштів, а також покриття потреби в середньо-і довгостроковому капіталі, необхідному для реалізації інвестицій в основний капітал;

2) залучення капіталу на умовах нижчого процентної ставки у порівнянні з ресурсами фінансово-кредитних інститутів;

3) забезпечення фінансування інвестиційного проекту;

6) створення біржової та кредитної історії для отримання більш пільгових умов фінансування як на міжнародних ринках так i всередині країни.

Вибір параметрів облігаційної позики як засобу фінансування залежить від мети залучення капіталу $\mathrm{i}$ розмірів самого підприємства. В умовах стабільної фінансової системи облігації суб'єктів господарювання стають інвестиційно-привабливими для професійних та інших учасників ринку цінних паперів.

Зазначимо, під час прийняття управлінських рішень щодо емісії корпоративних облігацій підприємств необхідно враховувати наступні умови та положення [12]:
1) згідно з законодавством не можна за рахунок емісії облігації формувати, поповнювати статутний фонд та покривати збитки;

2) умовою випуску облігацій підприємств в Україні є обмеження їх емісії до повної оплати всіх випущених акцій;

3) сума емітованих облігацій не може перевищувати трикратного розміру власного капіталу або розміру забезпечення;

4) у разі використання боргових цінних паперів, підвищується вплив фінансового ризику на діяльність підприємств у короткостроковому періоді;

5) облігації дозволяють планувати витрати на обслуговування боргу в силу різноманітності їх видів, можливості розповсюдження, методів погашення;

6) використання біржової інфраструктури та залучення професійних посередників дозволяе мінімізувати емісійні витрати підприємств.

Вартість облігаційного фінансування для корпоративних емітентів істотно диференційована в результаті різного рівня кредитної якості емітентів і, відповідно, рівнем попиту на їх боргові зобов'язання з боку інвесторів. Найбільш вигідні умови фінансування отримують емітенти "першого ешелону". Емісійна активність суб'єктів господарювання щодо випуску корпоративних облігацій наведена в табл. 1.

Незважаючи на пожвавлення ринку корпоративних облігацій за останні роки, цей сегмент фондового ринку є недостатньо розвинений. У 2019 році відбулося зменшення емісійної активності суб'єктів господарювання за кількістю та обсягом випусків облігацій (у порівнянні з 2018 р. обсяг зареєстрованих випусків облігацій зменшення на $27,5 \%$, у порівнянні з 2014 р. - зменшення на 61,4\%). Середня вартість випуску облігацій поступово зростає.

Таблиця 1: Емісійна активність суб' єктів господарювання щодо випуску облігацій за 2014-2019 pp.

\begin{tabular}{|l|c|c|c|c|c|c|}
\hline \multirow{2}{*}{ Показник } & \multicolumn{7}{c|}{ Роки } \\
\cline { 2 - 7 } & 2014 & 2015 & 2016 & 2017 & 2018 & 2019 \\
\hline $\begin{array}{l}\text { Обсяг зареєстрованих } \\
\text { випусків облігацій, млрд. грн. }\end{array}$ & 29,01 & 11,42 & 5,52 & 8,35 & 15,46 & 11,21 \\
\hline $\begin{array}{l}\text { в \% до капіталу суб’єктів } \\
\text { господарювання }\end{array}$ & 0,68 & 0,19 & 0,08 & 0,12 & 0,20 & 0,16 \\
\hline Кількість випусків облігацій & 248 & 147 & 118 & 114 & 110 & 88 \\
\hline $\begin{array}{l}\text { Середня вартість випуску } \\
\text { облігацій, млрд. грн. }\end{array}$ & 0,12 & 0,08 & 0,05 & 0,07 & 0,14 & 0,13 \\
\hline
\end{tabular}


Динаміку емісійної активності щодо облігацій суб'єктів господарювання (рисунок 1) відображає поліноміальний тренд третього ступеня на низхідної гілки, коефіцієнт детермінації $\mathrm{R}^{2}=0,9822$, загальні потреби в капіталі за рахунок облігацій нової емісії у 2019 р. забезпечені на 0,16 \% (табл. 1).

Визначення залежності капіталу та емісійної активності щодо облігацій суб'єктів господарювання свідчить про нелінійній характер (рисунок 2). Залежність капіталу від емісій облігацій, випущених суб'єктами господарювання, характеризує поліноміальна функція 3 порядку: $\mathrm{y}=-2,0581 \mathrm{x}^{3}+90,604 \mathrm{x}^{2}$ $122,7 \mathrm{x}+10863$. Коефіцієнт детермінації $\mathrm{R}^{2}=0,8364$.

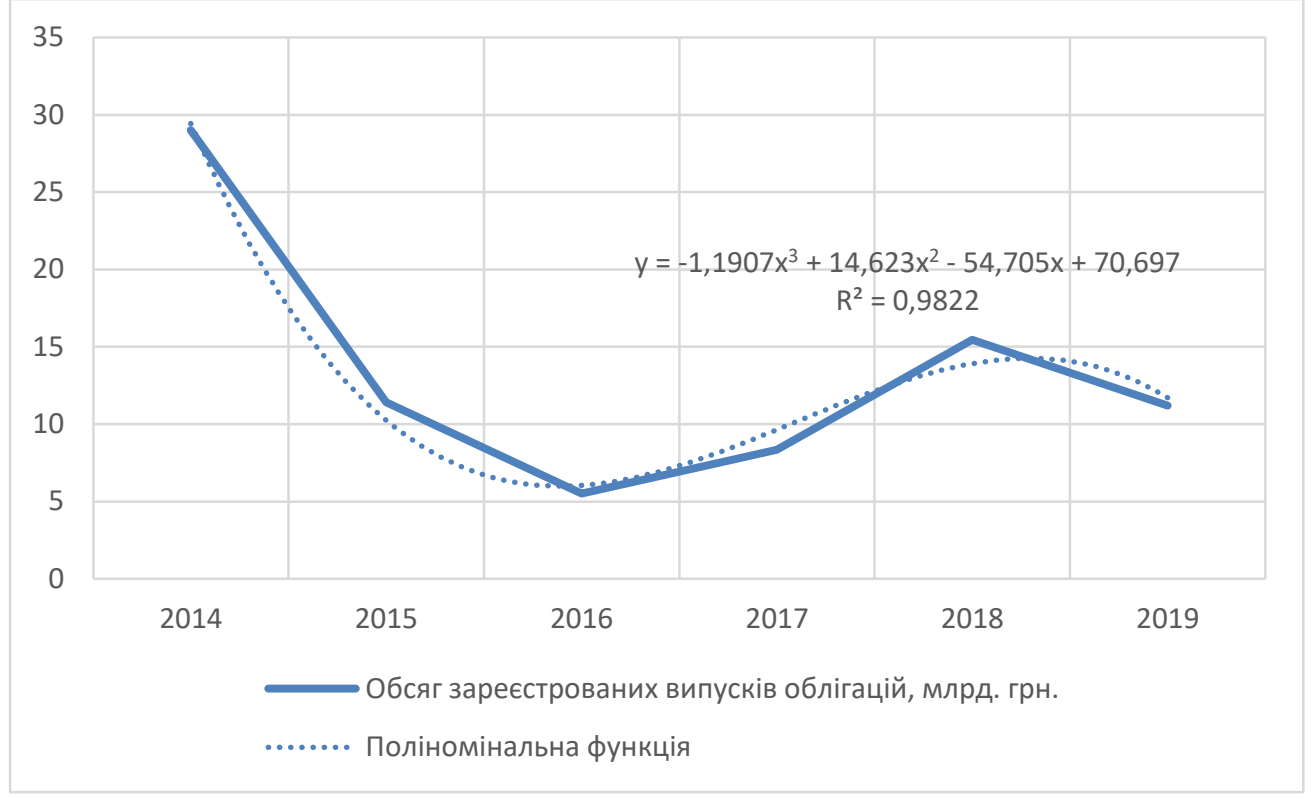

Рисунок 1 - Емісійна активність щодо облігацій суб’єктів господарювання Джерело: складено автором на підставі [13]

За обсягами залучений капітал, який отримано за рахунок емісії облігацій (у 2019 p. $-0,16 \%), \epsilon$ нижчим за величиною чистого прибутку, емісії акцій та банківських кредитів про що свідчить порівняння їх 3 капіталом суб'єктів господарювання.

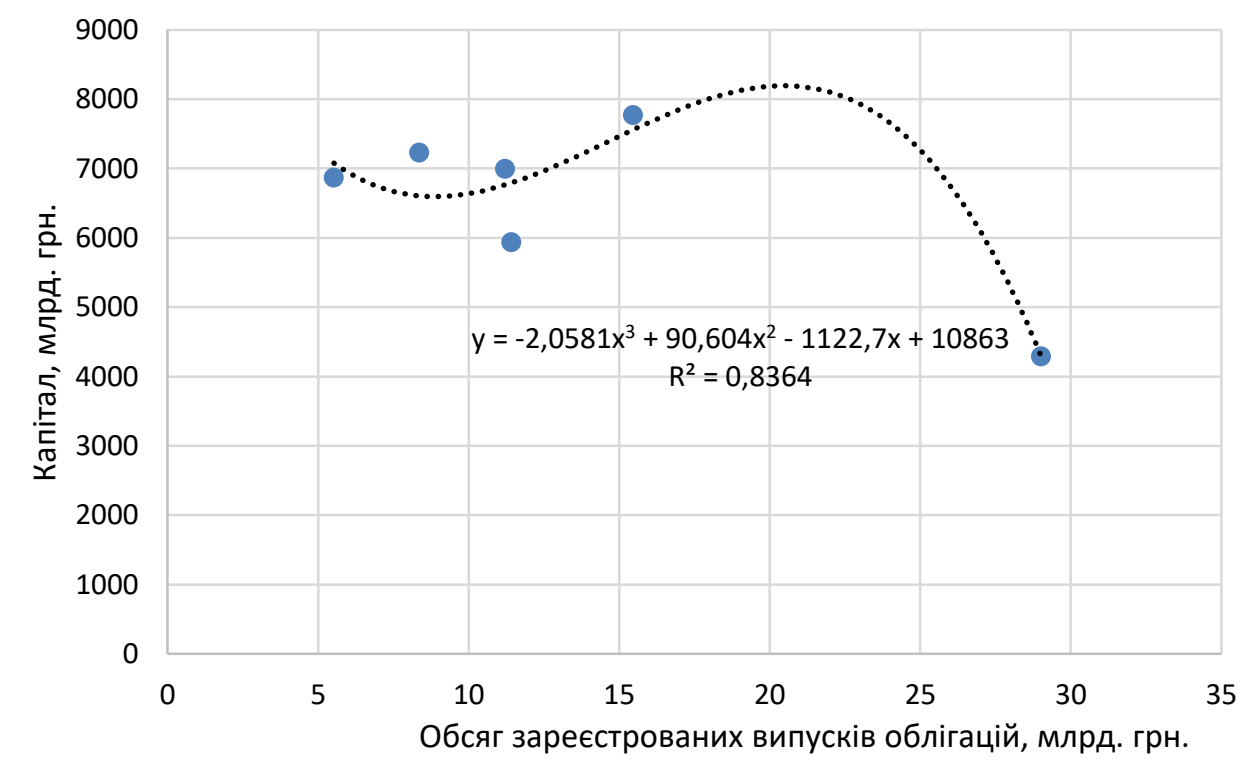

Рисунок 2 - Зв'язок капіталу та обсягом емісії облігації суб'єктів господарювання Джерело: складено автором на підставі $[13,14]$ 
Вторинний ринок корпоративних облігацій характеризувався зниженням обсягу торгів протягом 2017-2018 pp. (у 2016 p. становив 55,44 млрд. грн., у 2017 р. - 29,8 млрд. грн., у 2018 - 43,95 млрд. грн.) та збільшенням у 2019 до 43,95 млрд. грн. [13] Облігації українських підприємств становлять незначну частку цінних паперів в загальному обсягу торгів (3\%-6\%), у 2015 р. вона мала мінімальне значення 2,47\%, у 2017 p. - максимальне 6,34\%. Основними причинами низького попиту на корпоративні облігації є значний рівень ризику, пов'язаного зі строком позики, недовіра вітчизняних інвесторів до ринку облігацій, низька кредитоспроможність суб'єктів господарювання.

Висновки та перспективи подальших досліджень. 1. В умовах обмежених ресурсів комерційних банків та високої вартості традиційного кредитування потенційним джерелом фінансування розвитку суб'єктів господарювання $\epsilon$ залучення капіталу шляхом емісії корпоративних облігацій. 2. Трендовий аналіз емісійної активності суб'єктів господарювання щодо облігацій суб'єктів господарювання свідчить про недостатню розвиненість цього сегменту фондового ринку, незважаючи на пожвавлення його пожвавлення за останні роки. Корпоративні облігації становлять незначну частку джерел фінансування суб'єктів господарювання у зв'язку зі значним рівнем ризику, пов'язаного зі строком позики, недовірою інвесторів до ринку облігацій, низькою кредитоспроможністю суб'єктів господарювання. 3. В процесі дослідження фінансового потенціалу розвитку суб'єктів господарювання слід враховувати залежність сформованого капіталу та емісійної активності, активність на вторинному ринку облігацій суб'єктів господарювання. Залежність капіталу від емісій облігацій, випущених суб'єктами господарювання носить нелінійний характер та описуються поліноміальною функцією третього порядку. Визначені залежності дозволяють підвищити об'єктивність прогнозування в процесі формування стратегії фінансового регулювання розвитку суб'єктів господарювання.

Подальші дослідження будуть спрямовані на розробку рекомендацій щодо використання ресурсів фондів прямого інвестування для формування фінансового потенціалу розвитку суб' єктів господарювання.

\section{Література}

1. Fleming Michael J., Krishnan Neel, The Microstructure of the TIPS Market. Economic Policy Review. 2012. [Електронний реcyp]. URL: https://ssrn.com/abstract=1976375

2. Bruno Biais, Richard Green, 2019. The Microstructure of the Bond Market in the 20th Century, Review of Economic Dynamics. Elsevier for the Society for Economic Dynamics. Vol. 33. P. 250-271.

3. Heck Stephanie. Corporate bond yields and returns: a survey. Financial Markets and Portfolio Management. 2021. DOI: 10.1007/s11408-021-00394-4.

4. Guo Haifeng, Kontonikas, Alexandros, Maio, Paulo. Monetary Policy and Corporate Bond Returns. Review of Asset Pricing Studies. 2020. №10. Vol. 3. P. 441-489.

5. Nouvellon, Edouard, Pirotte Speder, Hugues. Can an equity structure dominate the risk-return profile of corporate bonds? Journal of Asset Management. 2021. № 22. P. 1-14.

6. Білоус I.В. Сучасні тенденції функціонування ринку корпоративних облігацій в Україні. Вчені записки Таврійського начіонального університету імені B. I. Вернадського. Серія: Економіка і управління. 2018. T. 29(68), № 6. C. 124-128.

7. Кужелєв М. О., Стабіас С. М. Пріоритети розвитку ринку корпоративних цінних паперів в Україні: монографія. Київ: «Центр учбової літератури», 2020. 176 с.

8. Руденко В. В. Перспективи використання корпоративних облігацій як джерела залучення фінансових ресурсів в Україні. Східна Свропа: економіка, бізнес та управління. 2017. № 7. [Електронний ресур]. URL: http://easterneurope-

ebm.in.ua/journal/7_2017/52.pdf. (дата звернення 20.01.2021).

9. Стецько М.В. Інструментарій корпоративних облігацій у фінансуванні підприємств. Економічний аналіз. 2017. Т. 27. № 2. С. 57-67.

10. Якушева I. Є. Ринок облігацій в України: стан, тенденції і перспективи розвитку. Ефективна економіка. 2021. № 4. [Електронний pecyp]. URL: http://www.economy.nayka.com.ua/?op=1\&z=8 809 (дата звернення: 20.05.2021).

11. Григораш Т. Ф., Мягков О. С., Воєводський Г. Ю. Облігації як інструмент залучення грошових ресурсів. Гроші, фінанси i кредит. 2019. Випуск 3(14). С. 362-368. 
12. Середа О.О. Використання корпоративних облігацій як інструмента залучення фінансових ресурсів в Україні. Пріоритети розвитку фінансової системи: традииї, моделі, перспективи: матеріали V міжнар. наук.практ. інтернет-конференції, м. Сєвєродонецьк, 12.04.-13.04.2018 p. Сєвєродонецьк: СНУ ім. В. Даля, 2018. С. 63-65.

13. Річні звіти НКЦПФР. Офіційний сайт Національної комісії з цінних паперів та фондового ринку. [Електронний ресур]. URL: https://www.nssmc.gov.ua/reports/ (дата звернення 12.12.2020).

14. Офіційний сайт Державної служби статистики України. [Електронний ресур]. URL: http://www.ukrstat.gov.ua/ (дата звернення 12.12.2020).

\section{References}

1. Fleming, M. J., Krishnan, N. (2012). The Microstructure of the TIPS Market. Economic Policy Review. Retrieved from: https://ssrn.com/abstract=1976375

2. Biais, B., Green, R. (2019). The Microstructure of the Bond Market in the 20th Century. Review of Economic Dynamics. Elsevier for the Society for Economic Dynamics, 33, 250 271.

3. Stephanie, H. (2021). Corporate bond yields and returns: a survey. Financial Markets and Portfolio Management. DOI: 10.1007 / s11408-021-00394-4.

4. Guo, H., Kontonikas, A. and Maio, P. (2020). Monetary Policy and Corporate rate Bond Returns. Review of Asset Pricing Studies, 10 (3), 441-489.

5. Nouvellon, E., Pirotte, S. and Hugues, A. (2021). Can an equity structure dominate the risk-return profile of corporate bonds? Journal of Asset Management, 22, 1-14.

6. Belous, I. (2018). Current trends in the functioning of the corporate bond market in Ukraine. Scientific notes of Tavriya National

\section{Стаття надійшла}

до редакції : 12.05.2021 p.
University named after VI Vernadsky. Series: Economics and Management, 29(68), 6, 124128.

7. Kuzhelev, M. O., Stabias, S. M. (2020). Priorities of development of the market of corporate securities in Ukraine: monograph. Kyiv: Center for Educational Literature, 176.

8. Rudenko, V. V. (2017). Prospects for the use of corporate bonds as a source of financial resources in Ukraine. Eastern Europe: Economy, Business and Management, 7. Retrieved from: http://easterneuropeebm.in.ua/journal/7_2017/52.pdf. (date of application 20.01.2021).

9. Stetsko, M. V. (2017). Toolkit of corporate bonds in enterprise financing. Economic analysis, 27(2), 57-67.

10. Yakusheva, I. E. (2021). Bond market in Ukraine: status, trends and prospects for development. Efficient economy, 4. Retrieved from:

http://www.economy.nayka.com.ua/?op=1\&z=8 809 (access date: 20.05.2021).

11. Grigorash, T. F., Myagkov, O.S., Voevodsky, G. Yu. (2019). Bonds as a tool to attract monetary resources. Money, finance and credit, 3(14), 362-368.

12. Sereda, O. O. (2018). The use of corporate bonds as a tool to attract financial resources in Ukraine. Priorities of financial system development: traditions, models, perspectives: materials of $\mathrm{V}$ international. scientific-practical Internet conference, Severodonetsk, April 12 April 13, 2018. Severodonetsk: V. Dahl EUNU, 63-65.

13. Annual reports of the NSSMC. Official site of the National Commission on Securities and Stock Market. Retrieved from: https://www.nssmc.gov.ua/reports/ (accessed 12.12.2020).

14. Official site of the State Statistics Service of Ukraine. Retrieved from: http://www.ukrstat.gov.ua/ (access date 12.12.2020).

\section{Стаття прийнята}

до друку: 30.06.2021 p.

\section{Бібліографічний опис для цитування :}

Середа О. О. Корпоративні облігації як джерело розвитку фінансового потенціалу суб'єктів господарювання / О. О. Середа // Часопис економічних реформ. - 2021. - № 2(42). C. 55-61. 